\title{
The Integrated Approach to the Teaching of Geometric-Graphical Disciplines at the University
}

\author{
Rushana R. Anamova ${ }^{1}$, Tatyana M. Khvesyuk ${ }^{2}$ \\ 1 Moscow Aviation Institute (National Research University), Department of Engineering Graphics, 4 Volokolamskoe \\ shosse, RU-125993 Moscow, Russian Federation, anamova5078@kpi.com.de \\ 2 Moscow Aviation Institute (National Research University), Department of Engineering Graphics, 4 Volokolamskoe \\ shosse, RU-125993 Moscow, Russian Federation, khvesyuk5078@kpi.com.de
}

\begin{abstract}
The article proposes testing on the basis of a model for teaching geometricgraphical disciplines for students of technical specialities. The novelty of the study is determined by the possibilities of increasing the professional competence of students by applying the most effective pedagogical trajectory in the learning process. Practical significance is determined by the necessity to improve the quality training of students as a basis for the study of subsequent special disciplines.
\end{abstract}

Keywords: higher education, geometric-graphical disciplines, pedagogical trajectory, professional competence.

\section{Introduction}

The analysis of the practical base on the formation of professional competence among students of technical universities gave grounds to assert that it is geometric-graphical disciplines, which include disciplines that study the rules for displaying spatial objects on the plane - descriptive geometry, engineering graphics, engineering and computer graphics, applied geometry - are the basis for this process (Kuchkarova \& Achilova, 2019). The purpose of these disciplines is not only to instil in student's fundamental knowledge in the field of using standards for design documentation but also to develop the student's spatial imagination, his ability to offer his own creative, non-standard 
design solutions, to work productively in a team when designing products for various purposes. The development of such competencies of students of technical universities is based on fundamental knowledge (Clark et al., 2008), practical experience gained in the framework of educational projects, and is aimed at improving the intellectual, creative qualities of an individual, as well as developing professional thinking and a culture of social communication, adaptation and mobility of a graduate (Alhajri, 2010).

According to the purpose of studying geometric-graphical disciplines, the basic general scientific principles, on which the educational process is built, were identified: fundamentality, systematic relations with the achievements of other sciences and with special disciplines (the so-called "interdisciplinary" connections), the unity of the theory and practice of teaching (Lemke \& Engelhom, 1986). However, it is important to take into account the fact that these disciplines must necessarily be based on the provisions of the contextual approach, according to which the content of all academic disciplines without exception, regardless of their specificity, as well as educational and cognitive activity of students, must be oriented to the context of their future profession and specialisation of professional activities (Zhuykova et al., 2019).

When students study geometric-graphical disciplines, they should ensure that the knowledge, skills, and abilities that are acquired, have professional and personal significance for them (Littlejohn, 2017). In this regard, vocational training appears not only as a process of specially stimulated and active educational knowledge, continuously focused and personally focused on understanding the essence and ways of implementing the functions of further professional activity, but also as a means of their personal and professional self-development, development of all their readiness components to professional activities (Tikhonov-Bugrov et al., 2018). In this regard, the geometric-graphical disciplines included in the curriculum for the training of future technical specialists should not be designed in the form of a definite sign system that meets the semiotic (organisation of textual information), psychological and pedagogical (reflecting the patterns of assimilation of knowledge), scientific and organisational (a reliable reflection of the foundation of a scientific discipline) and professional (compliance with a specialist model) requirements, and as a subject of educational, quasi-professional, and educational-professional activities of a student as a future technical specialist (Anamova \& Nartova, 2019). It is in this aspect that knowledge from the very beginning will be assimilated in the context of this activity, and the knowledge itself will perform the functions of an indicative basis of activity and means of its regulation.

It should also be noted that one of the main conditions for organising an effective educational process is a high level of teacher competence. A modern teacher should have professional (pedagogical) mobility, improve pedagogical skills. Professional mobility is understood as susceptibility to new teaching methods and a new one, i.e., updated content in accordance with the level of development of science and technology. In a post-industrial society, changes in the educational sphere are systematically taking place: new methods of 
presenting material are being developed, the content of disciplines is changing, and new educational technologies are being introduced. In this regard, a teacher should know and be able to apply modern (including innovative) teaching methods and technologies. It should be noted that any new teaching method has its limitations (scope), disadvantages, and some old, proven teaching methods also have not lost their relevance and effectiveness. In addition, the level of training of students who enter the university is different, since their level of knowledge varies within the maximum and minimum passing score based on the results of passing the Unified State Exam.

There is also a different level of motivation, personal development, and social adaptation. These factors should be taken into account when forming the content of geometric-graphical disciplines and when planning the forms of classes. Thus, the teacher's task is to use both old and new teaching methods, and their combinations, taking into account the student's training level, i.e., to choose as efficiently as possible from the many possible pedagogical trajectories the most effective. The hypothesis of the study is that a comprehensive approach to teaching geometric-graphical disciplines, that is, the organisation of the process of teaching geometric-graphical disciplines taking into account the most effective pedagogical trajectory, will increase the level of professional competence of students.

\section{Literature Review}

Each discipline included in the curriculum for training a future technical specialist (including geometric-graphical disciplines) should be dynamic, comprehensive, consistent with the logic of the transition from training to future professional activity (Leonavičiene \& Suboč, 2014). The latter can be achieved when (Shangina, 2019):

- firstly, the subject of learning from the very beginning is placed in an active position, a purpose of which is gradually turning from a purely educational to a practically professional one;

- secondly, the requirements on the part of professional activity will become system-forming, capable of setting the contextual principle of building and deploying not only each academic discipline, but also the content of the entire training of a technical specialist;

- thirdly, the content of the discipline will be formed on the basis of three opposite directions - from the scientific field of knowledge, from the requirements of professional activity and from the requirements of continuous self-education, and professional self-development of a student, which should become leading.

The result of students studying the disciplines of the geometric block should be the following knowledge and skills (Cicalò et al., 2019):

- knowledge of the rules for design documentation for parts and assembly units; 
- the ability to analyse the shape of a spatial object;

- the ability to "read" the drawings, namely: to represent a shape of a product and its location in space relative to other objects from images in a drawing, read the dimensions of the elements of a product according to a drawing, be able to determine a number, shape, and dimensions of components of a product;

- the ability to correctly present in a drawing technical requirement for the manufacture of parts and assembly units;

- the ability to choose the most optimal ways of design documentation from the point of view of labour and time costs;

- the ability to predict and avoid mistakes in design of products that lead to defects.

The specified knowledge and skills serve as the basis for the formation of the following competencies of future technical specialists:

- the ability to create and maintain the documentation necessary to support all stages of the life cycle of the design being developed;

- willingness to present a scientific picture of the world that is adequate to the current level of knowledge based on knowledge of the basic principles, laws, and methods of the natural sciences;

- willingness to participate in the development of design documentation for products for various purposes.

The listed competencies together constitute the professional competence of a student. Therefore, the educational process in geometric-graphical disciplines should be oriented towards (Núñez et al., 2011):

- designing ways to obtain new knowledge, that is, that knowledge that is not in the subjective experience of students, but that they need to solve their tasks and overcome problem situations that arise both in educational, professional, and social life (Nelin, 2004). Therefore, their content, forms and methods should be transformed from the traditional reproductive type to developing ones, which are characterised by the use of subject knowledge and skills as a means of developing the cognitive and social needs of students through the updating of their creative potential and the potential of teachers;

- the formation of not only cognitive, but also communicative abilities;

- the development of the need for continuing education and self-education;

- the development of the reflective sphere of a personality, without which professional, personal and social self-determination of students is impossible in a changing society, therefore, communicative developing technologies built on group forms of educational, professional and design-research activities play a special role. 


\section{Materials and Methods}

It is necessary to introduce the concept of "pedagogical trajectory". A pedagogical trajectory is a combination of methods, tools, forms, and a variable part of content. The content of the educational process includes the following components:

- an invariable component that does not depend on who is teaching the discipline: theorems, axioms, properties, rules, etc.;

- a variable component, which depends on the professional skill, experience, and qualifications of a teacher.

The variable part of the content, which is part of the pedagogical trajectory, is a method of presenting the material, includes various pedagogical tools. The composition of the variable part of the content, as a rule, includes a system of interdisciplinary relations (with special disciplines), since interdisciplinary communication is a means of presenting material in which the constant components of the content (theorems, axioms, properties and rules) are demonstrated using examples taken from the student's future professional activities. An effective pedagogical trajectory is understood as such a combination of methods, means, forms, and a variable part of content that allows students to fully master the course of geometric-graphical disciplines in accordance with the curriculum and work program of the discipline, i.e., to achieve the results of mastering and acquire/develop competencies necessary for the study of subsequent disciplines and (or) the implementation of future professional activities.

When choosing a pedagogical trajectory, it is necessary to focus on the initial conditions (not for an individual student, but for the whole group). Accordingly, for different groups with certain parameters, a different pedagogical trajectory can be chosen. The criteria for choosing a pedagogical trajectory are the parameters of the groups: the level of basic knowledge in geometry, the level of development of spatial imagination, cognitive abilities. Group parameters can be determined using input control (testing). The process of choosing a pedagogical trajectory is a multiple choice, which can be represented in the form of a graph. The parameters of groups are presented as starting points (initial vertices of the graph). The ultimate goal (the endpoint is the top of the graph) is for students of groups to achieve a certain level of knowledge, skills (developing the necessary competencies and development results in accordance with the requirements of the work program). The path from the start point to the endpoint can be different (it can go through different vertices of the graph). The edges of the graph have weights. The weight of the rib depends on the effectiveness of the combination of certain methods, means, forms, and the effectiveness of their application for a particular group of students (based on the initial parameters of the group). The most effective pedagogical trajectory is such a trajectory (the path from the point "group" to the point "goal") for which the sum of the weights of the graph edges is maximum. 
To achieve the purpose of the study, a series of pedagogical experiments were conducted, during which the level of formation of professional competencies of students of technical specialities was evaluated, as well as the development results acquired by them upon completion of the study of the discipline. It was possible to evaluate the formation of the competence "Willingness to participate in the development of design documentation for products for various purposes" through the accumulation by students of individual social and professional experience in various real and simulated situations, "immersion" in the special conditions of design and research activities. This is defined as an enriched socio-professional environment - a special system of influences and opportunities contained in the social and spatial-subject environment of higher education institutions (Trofimov \& Korolev, 2019). An important task of the enriched social and professional environment is to ensure the social, and professional identification of students, which provides mechanisms for their socialisation, encourages active creative search, argumentation and upholding their professional position among colleagues. It is social and professional identification that is the process that ensures the formation of the social and professional identity of future specialists as a component of their technical competence (Dulić et al., 2019).

Based on the fact that social identification occurs through the perception by a person of the characteristic features of a particular social group, comparing them with the signs of other groups and identifying themselves as a member of this group, and professional identification occurs through the recognition of their role in the team in carrying out projects focused on professional activities, then the educational environment of the university should provide the conditions for such self-categorisation (Moszkowicz, 2013). In addition, for successful social and professional identification, it is significant that there is an opportunity in the educational environment to assess the attributes of a social (professional) group and a positive emotional experience of belonging to it, i.e., to affectively identify emotional attachment to a group (Taras, 2019). The motivational component of social and professional identification ensures students' participation in group activities, which emphasises their social authenticity in certain social rites, traditional actions that encourage the adoption of group values (Gachago et al., 2011).

It is extremely important, in authors' opinion, to understand that, depending on the awareness of the importance of the educational environment of higher education institutions by subjects of the educational activity (primarily administration, teachers, curators of student groups), it can be spontaneous, unorganised (its factors affecting development individuals are unmanageable, in all their diversity), partially organised or organised (when its resources are used as forming means) (Guedes et al., 2012). A spontaneous educational environment in modern extremely risky social and cultural conditions can lead to social marginalisation - a person's loss of social values, social deprivation, maladaptation and disintegration, deviant and even delinquent, illegal behaviour (Lasserre, 2012). A spontaneous, uncontrolled educational environment can become a factor in the 
destruction of the prerequisites for the technical competence of future specialists formed at previous age stages, and lead to their negative social development.

To confirm or refute the hypothesis of the study, namely, that an integrated approach to teaching geometric-graphical disciplines, that is, organising the process of teaching geometric-graphical disciplines taking into account the most effective pedagogical trajectory, will increase the level of professional competence of students, it is necessary to compare the empirical data obtained at the ascertaining and control stages of the experiment in the experimental and control groups. The authors analysed the results of diagnostic sections for each component of professional competence of students of technical specialities of experimental and control groups, and then - in general, according to the general coefficient of its formation. It is worth recalling that professional competence, when it comes to geometric-graphical disciplines, means:

- the ability to create and maintain the documentation necessary to support all stages of the life cycle of the design being developed;

- willingness to present a scientific picture of the world that is adequate to the current level of knowledge based on knowledge of the basic principles, laws, and methods of the natural sciences;

- willingness to participate in the development of design documentation for products for various purposes.

Therefore, to determine the levels of professional competence of students of technical specialities, it is necessary to consider the results of diagnostics by the following methods: the test of the formation of knowledge and skills, as well as the questionnaire of self-esteem (reflection) of students regarding the formation of knowledge and skills.

The study took place on the basis of the Moscow Aviation Institute (National Research University) (Moscow, Russian Federation). The study involved 87 future specialists in chemical production. All participants were divided into two groups - experimental (students of 1-2 courses, 50 people) and control (students of 3-4 courses, 37 people). The experimental group was divided into three subgroups for convenience in obtaining the results - EG1 (17 people), EG2 (18 people), EG3 (15 people). The control group was divided into two subgroups - 1CG (20 people), 2CG (17 people). The cognitive component of the technical competence of chemical production specialists was diagnosed thanks to the author's didactic test, which determined the degree of students' awareness of the essence of technical competence, its structure, principles and development mechanisms.

The constructive component of the technical competence of specialists in chemical production was studied using three methods: Method " $\mathrm{Q}$ - sorting: diagnostics of the main tendencies of behaviour in a real group", Questionnaire of tolerance-intolerance to uncertainty and the author's Scale of self-assessment of social skills. The students conducted a generalized analysis of self-assessment of their own social skills. In order to assess the reliability of the difference in the coefficients of the formation of technical 
competence of specialists in the chemical production of experimental groups before and after the introduction of formative measures, the method of paired comparisons was applied, which allows one to compare the two obtained coefficients.

Thus, the study was carried out in three stages. The following were carried out: the ascertaining stage, at which the primary level of formation of technical competence was studied, the forming stage, which was aimed at the introduction of certain experimental factors and the control stage, providing for the secondary diagnostics of the level of formation of the technical competence of specialists in chemical production after the introduction of experimental factors.

\section{Results and Discussion}

According to the results of applying the test of the formation of knowledge and skills at the ascertaining stage of the pedagogical experiment, students of all experimental and control groups had the medium level of knowledge formation and predominantly low level of skill formation (Fig. 1).

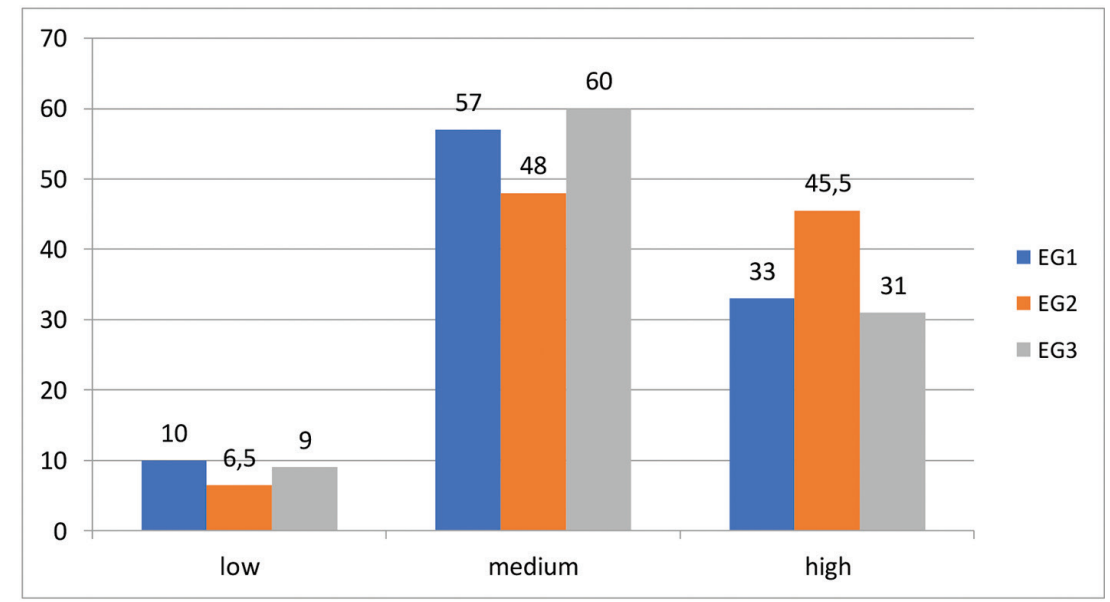

Figure 1. The Primary Level of Knowledge and Skills Formation of Students of Experimental Groups

A low level of knowledge and skills formation was revealed in $10 \%$ of students in the EG1, 6.5\% of students in the EG2, and 9\% of students in the EG3. The results of the secondary measurement showed a significant increase in the levels of knowledge and skills of students in experimental groups: a low level was found only in $8 \%$ of students in the EG1, 5\% of students in the EG2 and $0 \%$ in the EG3 (versus 10\%, 6.5\% and 9\%, respectively, in the primary measurement); the medium level was diagnosed in $50 \%$ of 
students in the EG1, 56\% in the EG2, 53\% in the EG3 (versus $57 \%, 48 \%$, and $60 \%$, respectively, at the ascertaining stage); a high level was observed in $42 \%$ of students in the EG1, 39\% in the EG2, and 47\% in the EG3 (versus 33\%, 45.5\%, and 31\%, respectively, at the ascertaining stage) (Fig. 2).

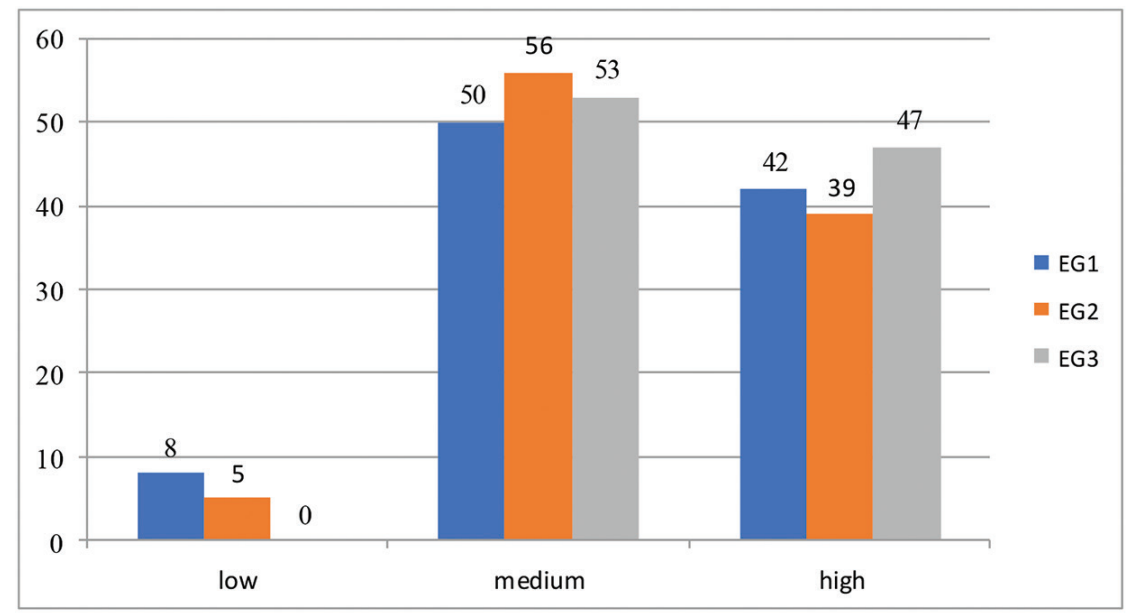

Figure 2. The Secondary Level of Knowledge and Skills Formation of Students of Experimental Groups

According to the methodology for determining the level of knowledge and skills formation of students in relation to the educational process of geometric-graphical disciplines, data were obtained that testify to significant changes in the level of professional competence formation of students of technical specialities in experimental groups. Thus, according to the results of a stating measurement, the low level of reflection of knowledge and skills as a whole was found in $28.5 \%$ of students in the EG1 group, $33 \%$ in the EG2, and $26 \%$ in the EG3; the medium level $-60 \%$ of students of the EG1 group, $52.5 \%$ - EG2, and $57 \%$ - EG3; the high level - 11.5\% of students of the EG1 group, 14.5\% - EG2, and 17\% - EG3 (Fig. 3). 


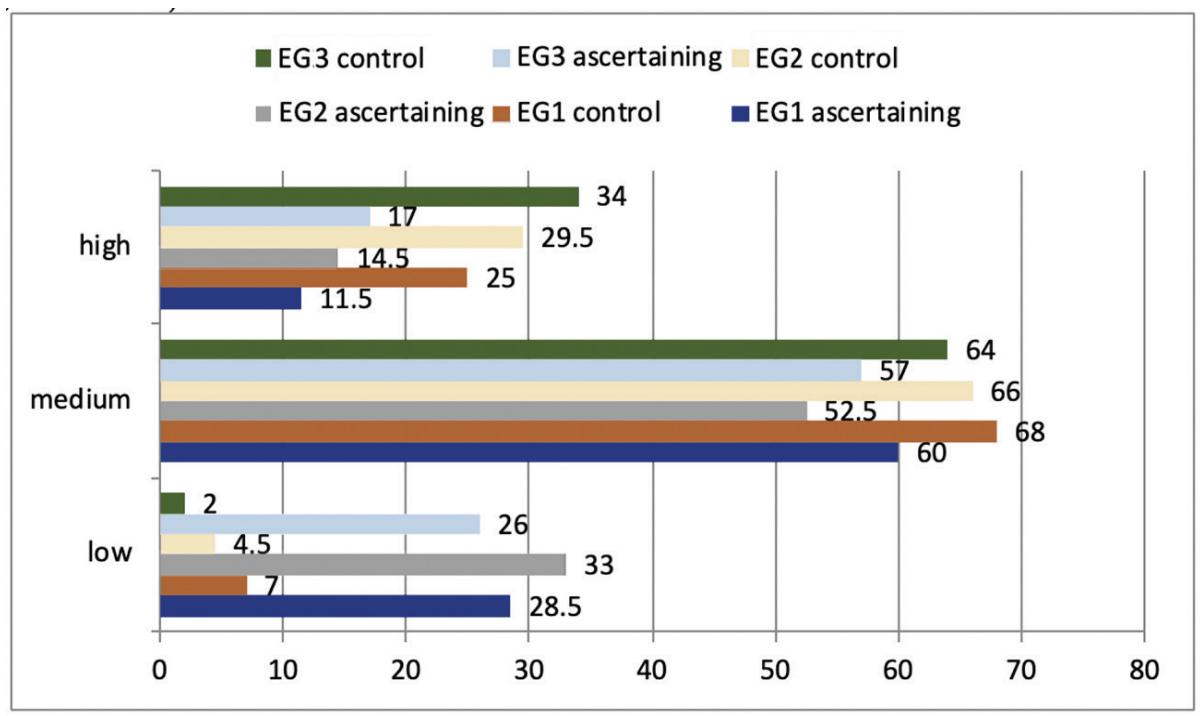

Figure 3. The Dynamics of the Levels of Reflection of Knowledge and Skills of Students of Experimental Groups

After the implementation of formative measures according to the results of the control measurement, the level of reflection of knowledge and skills of students of experimental groups significantly increased, as evidenced by the growth in the number of students with its high (EG1 - 25\%, EG2 - 29.5\%, EG3 - 34\%) and medium (EG1 - 68\%, EG2 - 66\%, EG3 - 64\%) levels and a decrease in the number of students with a low level of reflection of their own knowledge and skills (EG1 - 7\%, EG2 - 4.5\%, EG3 - 2\%). Particularly noteworthy is the dynamics of the level of reflection of knowledge and skills of students of experimental groups. So, if at the ascertaining stage, the low level of reflection of knowledge and skills was recorded in $28.5 \%$ of students of EG1, 33\% of EG2 and 26\% of EG3, then according to the results of the control measurement, most students showed medium and high levels, the low level was diagnosed only in 2\% of students EG3, that is, one of them. These data indicate significant positive changes in the formation of knowledge and skills of students of experimental groups. The cognitive component of the professional competence of students of technical specialities was diagnosed thanks to the author's didactic test, which determined the degree of students' awareness of the essence of the geometric-graphical discipline, its relations with other disciplines (previous and subsequent). The dynamics of the formation of this component of professional competence of students of technical specialities are presented in Fig. 4.

So, at the ascertaining stage, most students of the experimental groups had a low level of its formation (EG1 - 78.5\%, EG2 - 80.95\%, EG3 - 78.26\%), according to the results of the control measurement, data were obtained that illuminate the significant positive 
dynamics of students' awareness of the essence of the geometric-graphical discipline, its relations with other disciplines (previous and subsequent). $85.7 \%$ of students in the EG1, $80.95 \%$ in the EG2 and $69.56 \%$ in the EG3 have a high level; $14.3 \%$ of students in the EG1, $19.05 \%$ in the EG2, and $30.44 \%$ in the EG3 - average.

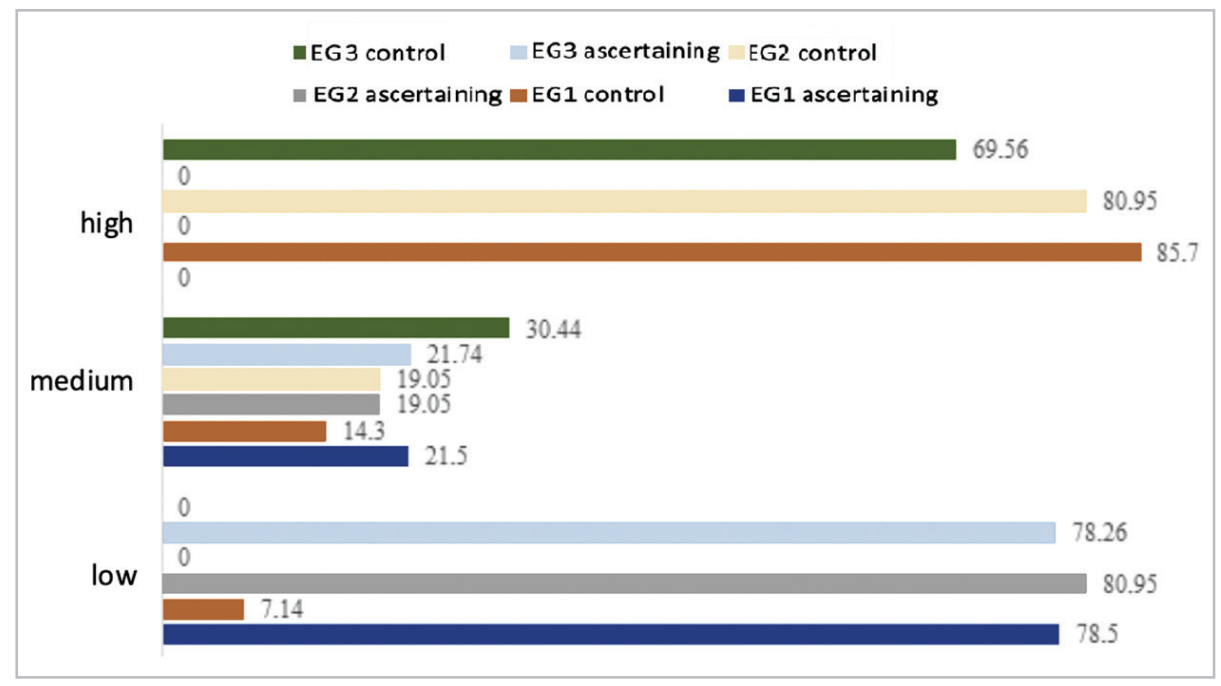

Figure 4. The Dynamics of the Levels of the Cognitive Component Formation of Professional Competence of Students of Experimental Groups

A low level of formation of the cognitive component of professional competence was not detected in any student of experimental groups (Fig. 4). According to the results of the diagnostics, it can be stated that students of experimental groups have significantly increased the level of awareness of the essence of geometric-graphical disciplines, which is the orientation basis of their professionally competent behaviour.

The constructive component of professional competence of students of technical specialities was studied using three methods: Methodology "Q - sorting: diagnosis of the main trends in behaviour in a real group", Questionnaire of tolerance-intolerance to uncertainty and the author's Self-assessment scale of professional skills. The results obtained were considered at the ascertaining and control cross-sections for each of the methods. So, according to the Methodology " $\mathrm{Q}$ - sorting: diagnosis of the main trends in behaviour in a real group", three main trends were determined - groups of social and professional skills that future technical specialists in their student group show:

1) the tendency to dependence-independence (the ability to independently make professionally significant decisions); 
2) the tendency of sociability-non-sociability (contact, the ability to discuss professional tasks with team members);

3) a tendency to struggle - rejection of the struggle (the ability to confidently and reasonably uphold one's professional point of view).

The authors analysed the dynamics of the formation of social and professional skills of students in each trend. According to the results of calculating the trend towards dependence-independence (the ability to independently make professionally significant decisions), at the ascertaining stage, data were obtained on the predominance of low and medium levels with the very low weight of a high level (EG1 - 7.15\%, EG2 - 0\%, EG3 $21.75 \%$ ) Control diagnostics showed an increase in the medium (EG1 - 35.8\%, EG2 33.4\%, EG3 - 43.48\%) and high (EG1 - 64.2\%, EG2 - 66.6\%, EG3 - 56.52\%) levels (Fig. 5).

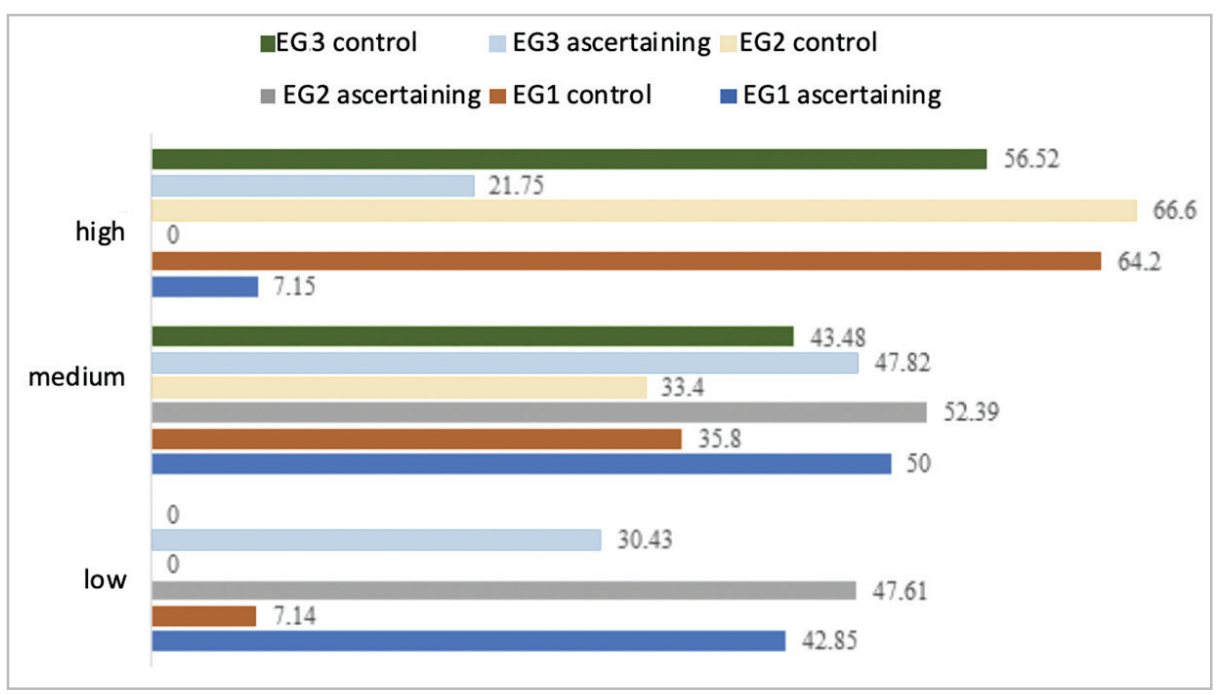

Figure 5. The Dynamics of the Levels of Formation of Social and Professional Skills of Students of Experimental Groups (According to the Trend of Dependence-Independence - the Ability to Independently Make Professionally Significant Decisions)

These data indicate that students of experimental groups, in which the methodology for determining the most effective pedagogical trajectory was applied, found the ability to independently make professionally significant decisions. Based on the results of calculating the sociability tendency, the ability to discuss professional tasks with team members was shown, the following data were obtained from the control measurement, namely: a certain positive dynamics in the levels of skills formation - low level reduction (from EG1 - 28.57\%, EG2 - 19.04\%, EG3 - 21.73\% to EG1, EG2, EG3 - 0\%) and a high level increase (from EG1 - 21.4\%, EG2 - 9.54\%, EG3 - 21.73\% to EG1- 50\%, EG2 - 66.7\%, EG3 - 34.79\%) (Fig. 6). 


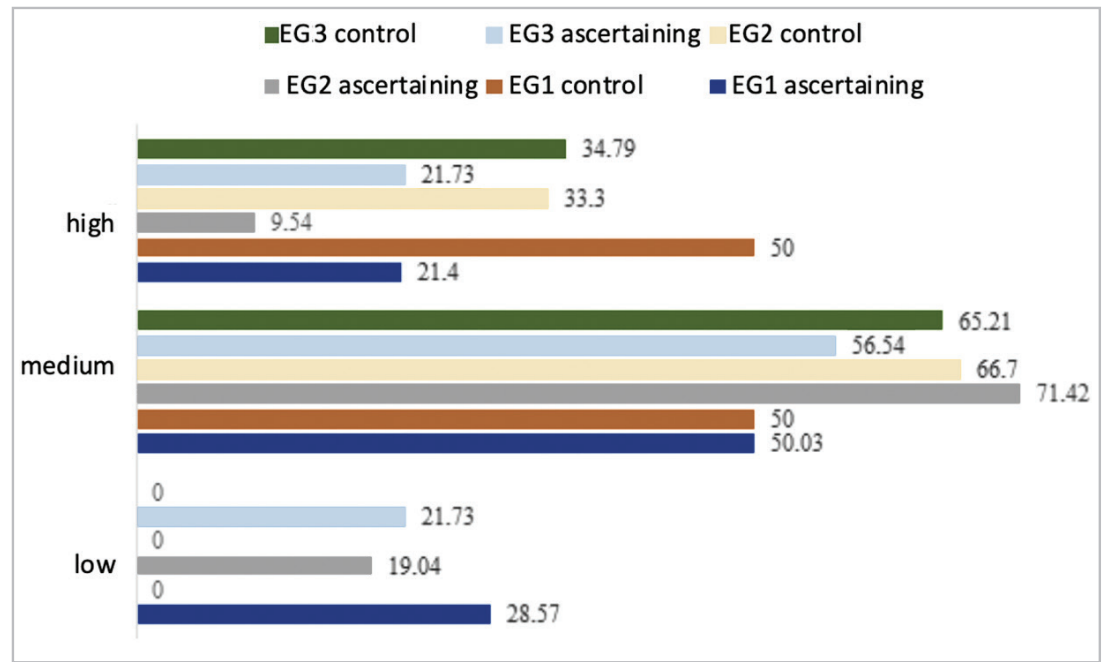

Figure 6. The Dynamics of the Levels of Formation of Social and Professional Skills of Students of Experimental Groups (On the Trend of Sociability)

According to the results of calculating the trend of the struggle, which determines the ability to confidently and reasonably uphold one's professional point of view, the results of the control measurement also determine the positive dynamics in all experimental groups (Fig. 7) - a decrease in the low level was recorded (with EG1 - 14.2\%, EG2 - 28.57\%, EG3 - 30.43\% to EG1, EG3 - 0\%, EG2 - 4.75\%), and a high level increase (with EG1 - 14.2\%, EG2 - 9.52\%, EG3 - 30.43\% to EG1 - 57.14\%, EG2 - $23.8 \%$, EG3 - 34.79\%).

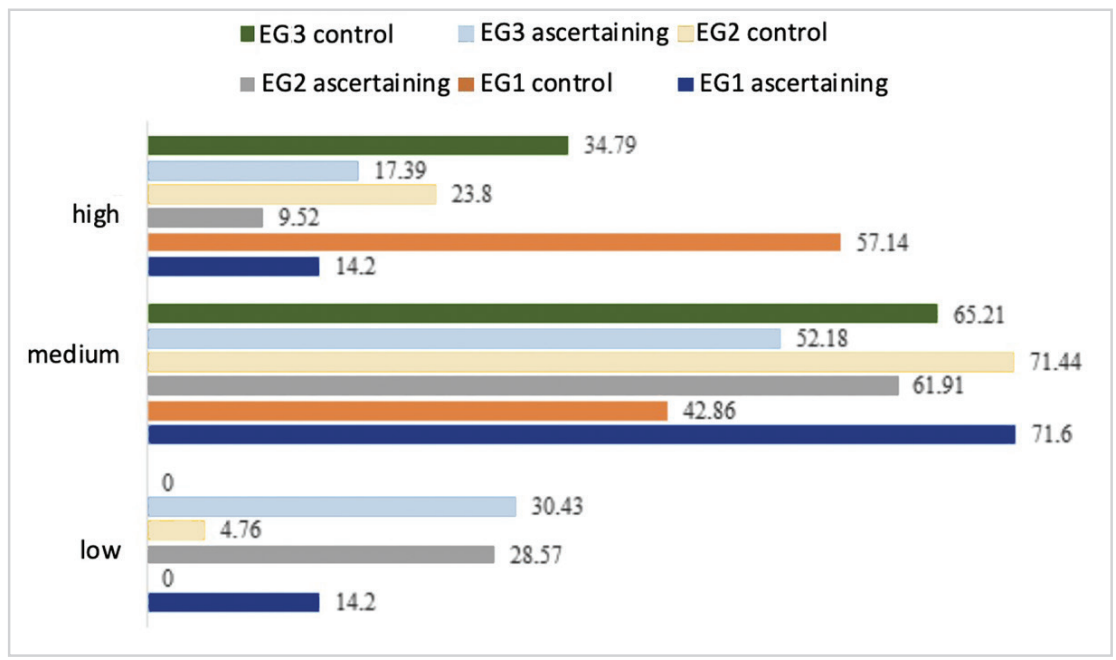

Figure 7. The Dynamics of the Levels of Formation of Social and Professional Skills of Students of experimental groups (According to the Trend of "Struggle") 
Using the questionnaire of tolerance-intolerance to uncertainty, data were obtained that testify to a general increase in the level of tolerance to uncertainty of students of all experimental groups, both in terms of their willingness to solve new professional problems and to choose the most complex tasks, aspirations for independence, going beyond accepted limitations and attractiveness professional tasks being solved, as well as in the aspect of understanding and accepting one's wrong when discussing professional tasks, stability in relations with others, the ability to defend one's point of view reasonably. This is manifested in the overall positive dynamics of the level of tolerance to uncertainty a decrease in the low level (from 14.2\% for students of the EG1, 38.09\% - EG2, 34.78\% EG3 to 0\% for students of EG1, 0\% - EG2, 0\% -EG3), growth high level (from 35.7\% for students - EG1, 0\% - EG2, 17.39\% - EG3 to 71.42\% for students of EG1, 33.34\% - EG2, $34.79 \%$ - EG3) (Fig. 8).

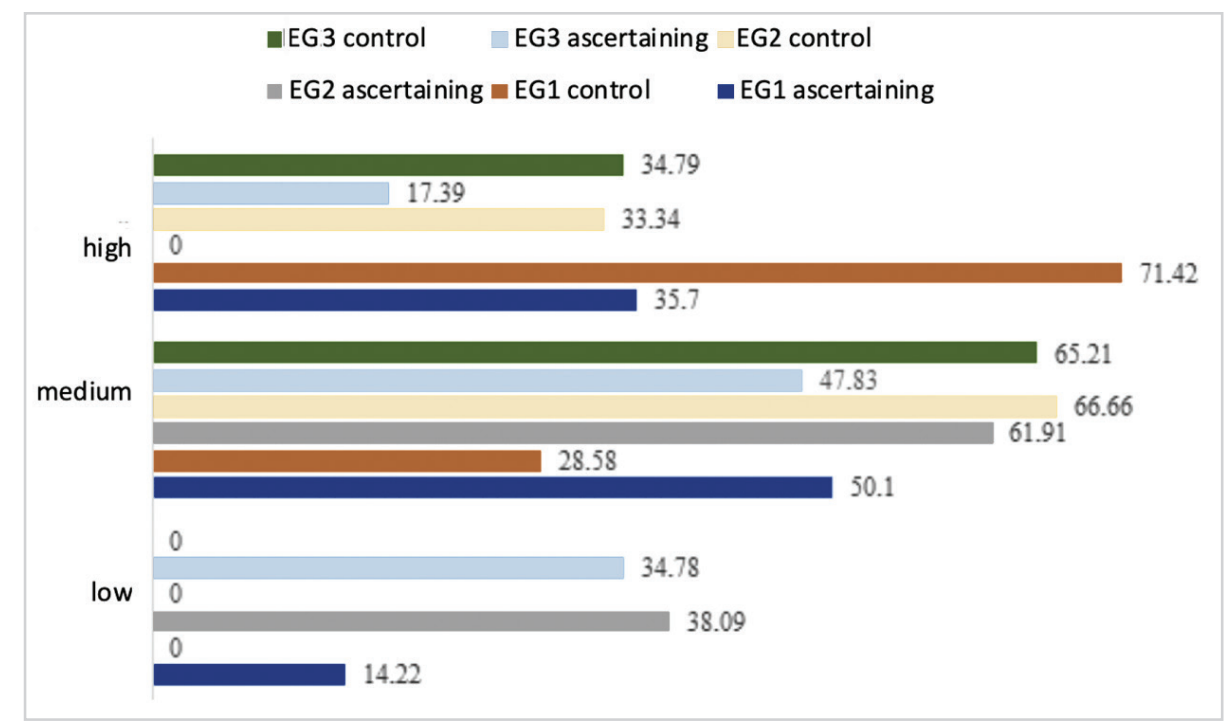

Figure 8. The Dynamics of the Levels of Formation of Social and Professional Skills of Students of Experimental Groups (Tolerance to Uncertainty)

According to the author's scale of self-assessment of professional skills, positive dynamics in the level of their formation among students of experimental groups were also tracked. This was manifested in a significant increase in their students' own ratings. Professional skills were evaluated in the following groups:

1) "analysis": the ability to analyse the source data of a task or to analyse a ready-made solution;

2) "synthesis": the ability to independently solve the problem on the basis of this example; 
3) "creativity": the ability to solve a problem for which an example was not given, as well as to offer a non-standard solution to a problem already solved previously.

So, if at the ascertaining section, students mainly assessed the level of formation of their skills as low and medium (Fig. 9). After the introduction of the most effective pedagogical trajectory, the level of self-esteem of professional skills increased significantly, as evidenced by assessments of their own professional skills at medium and high (points from 9 to 10) levels and the absence of low self-esteem (Fig. 10).

A generalised analysis of students' self-esteem of their own professional skills suggests that there is a steady positive dynamic in their level of formation, mainly from the low to the medium and high levels in all experimental groups. Secondary measurements of the levels of professional competence of students of technical specialities of experimental groups for all components and their comparison with primary indicators allow us to determine the effectiveness of previously justified and implemented organisational and pedagogical conditions.

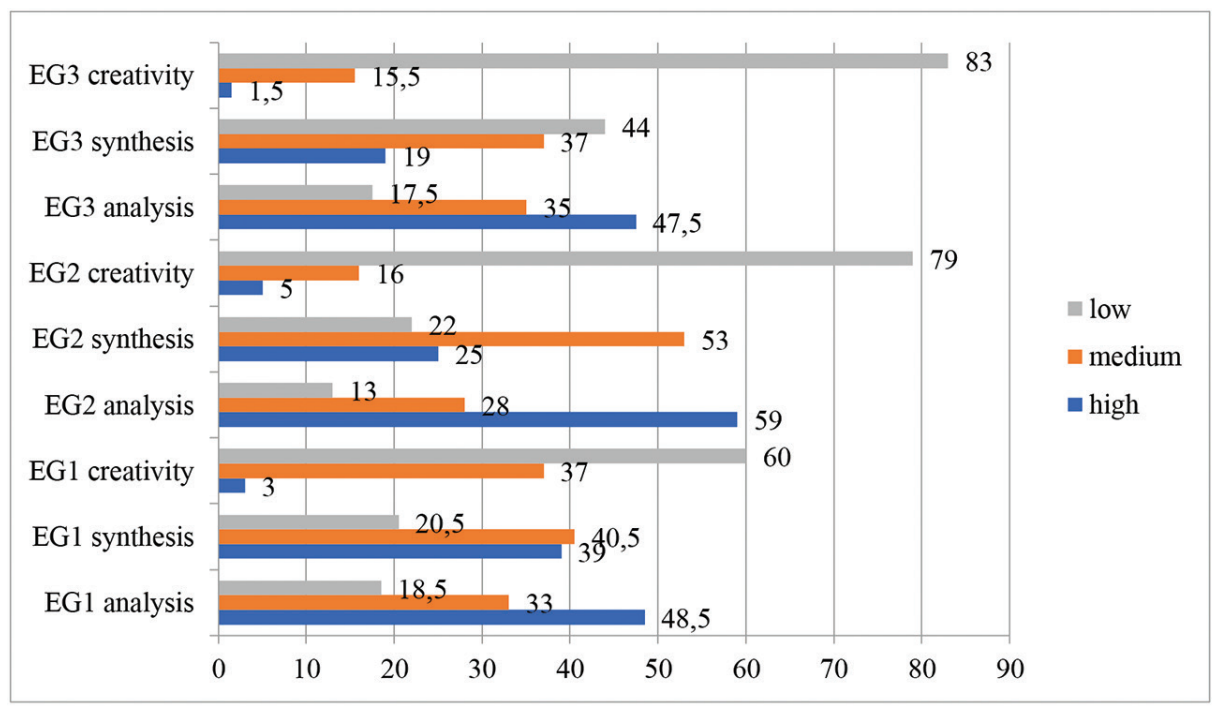

Figure 9. Self-esteem of Students of Experimental Groups of Professional Skills Formation (Ascertaining Cross-Section)

For the mathematical processing of the obtained data, it is necessary to find a common coefficient for measuring the arithmetic mean of all the coefficients of the formation of professional competence for each component. Since the general coefficient of the professional competence formation in students of technical specialities (CCF) is the sum of the coefficients for each component (value $\left(K_{\text {cost }}\right)$, cognitive $\left(K_{\text {cogn }}\right)$ and constructive $\left(K_{\text {constr }}\right)$, then it is equal to (Eq. 1): 


$$
K C K=\frac{K \cos t+K k \operatorname{kog} n+K \text { constr }}{3} K C K=\frac{K \cos t+K k o g n+K \operatorname{constr}}{3},
$$

where: CCF - the general coefficient of the formation of professional competence; $K_{\text {cost }}$ - the coefficient of formation of the value component; $K_{\text {kogn }}$ - the coefficient of the cognitive component formation; $K_{\text {constr }}$ - the coefficient of the structural component formation.

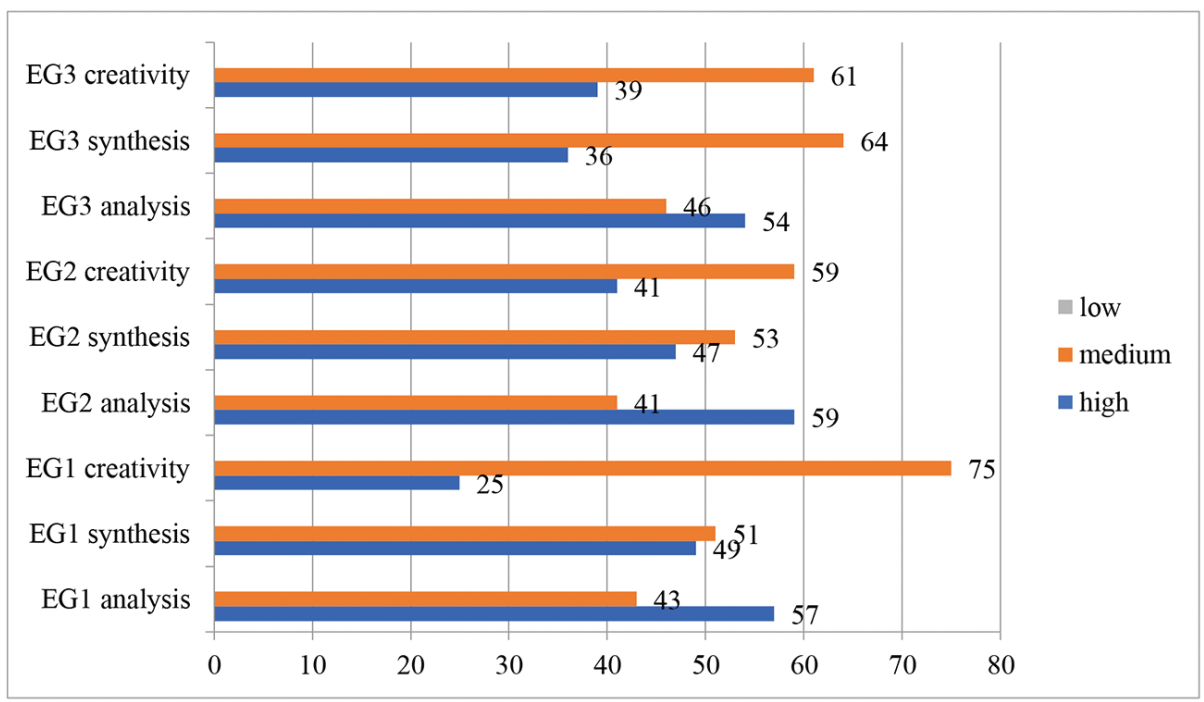

Figure 10. Self-esteem of Students of Experimental Groups of Professional Skills Formation (Control Cross-Section)

Since the formation coefficients of the value and structural components are complex, they consist of several indicators, namely:

- the coefficient of formation of the value component consists of the coefficient obtained by the test of knowledge and skills formation $\left(K_{\text {cost }}\right)$ and the coefficient obtained from the Questionnaire for self-esteem (reflection) of students regarding knowledge and skills formation $\left(K_{\text {cost } 2}\right)$;

- the coefficient of formation of the constructive component consists of the coefficient obtained by the Method "Q - sorting: diagnostics of the main behavioural trends in a real group" $\left(K_{\text {constr }}\right)$, the coefficient obtained from the Questionnaire for toleranceintolerance to uncertainty $\left(K_{\text {constr }}\right)$ and the coefficient according to the author's Professional skills self-assessment Scale $\left(K_{\text {constr } 3}\right)$. 
Therefore, the coefficient of formation of professional competence of students of technical specialities is calculated according to the formula (Eq. 2):

$$
\begin{aligned}
& K C K=\left(\frac{K \cos t 1+K \cos t 2}{2}+K k o g n+\frac{K \text { constr } 1+K \text { constr } 2+K \text { constr } 3}{3}\right) / 3 \\
& K C K=\left(\frac{K \cos t 1+K \cos t 2}{2}+K \text { kogn }+\frac{K \text { constr } 1+K \text { constr } 2+K \text { constr } 3}{3}\right) / 3
\end{aligned}
$$

Each of the above coefficients is calculated by the formula (Eq. 3):

$$
Q=p x_{b}+p x_{c}+n x_{h} Q=p x_{b}+p x_{c}+n x_{h},
$$

where: $Q$ - the total indicator of the sample size equal to the sum of $m, n, p$; $m$ - the number of indicators with a high level of formation of the sign; $x_{v}$ - is the weight of the attribute; $p$ - the number of indicators with an average (sufficient) level of formation of signs; $x_{c}$ - the weight of the attribute; $n$ - the number of indicators with a low level of formation of signs; $x_{h}$ - the weight of the attribute. If the weight of indicators with a high level of formation is 1 , with an average -0.5 , with a low -0 , then the formula is obtained (Eq. 4):

$$
K=\frac{m+0,5 p}{Q} K=\frac{m+0,5 p}{Q} .
$$

Calculation of the coefficients of the formation of professional competence in terms of value, cognitive and constructive components made it possible to determine the general coefficient of its formation among students of technical specialities of the experimental and control groups at the ascertaining and control stages of the pedagogical experiment (Table 1).

Table 1

The Dynamics of the Coefficients of the Formation of Professional Competence of Students of Technical Specialities

\begin{tabular}{lcccccc}
\hline \multirow{2}{*}{$\begin{array}{c}\text { Professional competency } \\
\text { component (coefficient) }\end{array}$} & \multicolumn{2}{c}{ EG1 } & \multicolumn{2}{c}{ EG2 } & \multicolumn{2}{c}{ EG3 } \\
\cline { 2 - 7 } & $\begin{array}{c}\text { Ascertai- } \\
\text { ning }\end{array}$ & Control & $\begin{array}{c}\text { Ascertai- } \\
\text { ning }\end{array}$ & Control & $\begin{array}{c}\text { Ascertai- } \\
\text { ning }\end{array}$ & Control \\
\hline Valuable & 0.28 & 0.72 & 0.3 & 0.65 & 0.27 & 0.69 \\
Cognitive & 0.18 & 0.81 & 0.12 & 0.74 & 0.09 & 0.86 \\
Constructive & 0.33 & 0.69 & 0.26 & 0.61 & 0.29 & 0.68 \\
General coefficient (CCF) & 0.263 & 0.74 & 0.226 & 0.66 & 0.216 & 0.74 \\
\hline
\end{tabular}


The distribution of the formation factors of the professional competence of students of technical specialities allows stating the following: if the coefficient is in the range from 0.00 to 0.32 , then the general level is low (initial), if between 0.33 to 0.66 - it is medium, if between 0.67 to 1.00 - it is high. Consequently, the obtained general coefficient of professional competence formation for students of technical specialities in all experimental groups was at a low level at the ascertaining stage, and at EG1 and EG3 at the control stage, at a high level, and in the EG2 at the medium level.

In order to assess the reliability of the difference in the formation coefficients of professional competence of students of technical specialities of experimental groups before and after the introduction of formative measures, the method of pairwise comparisons was applied, which allows comparing the two obtained coefficients. The error of differences between the means, calculated by the formula (Eq. 5):

$$
M_{d}=\sqrt{\frac{\sum(d-\bar{d})^{2}}{n(n-1)}} M_{d}=\sqrt{\frac{\sum(d-\bar{d})^{2}}{n(n-1)}}
$$

is 0.68 , the criterion of reliability of the difference of coefficients is 4.64 . The table value of the same indicator for (Eq. 6):

$$
\mathrm{n}=\mathrm{n}_{1}+\mathrm{n}_{2}-2
$$

(for a small sample) and significance level $\mathrm{P}=0.1$ will be equal to 1.860 .

Table 2

Dynamics of the Formation Factors of Professional Competence of Students of Technical Specialities (Control Groups)

\begin{tabular}{lcccc}
\hline \multirow{2}{*}{$\begin{array}{l}\text { Professional competency } \\
\text { component (coefficient) }\end{array}$} & \multicolumn{4}{c}{ Control groups } \\
\cline { 2 - 5 } & Ascertaining & Control & Ascertaining & Control \\
\hline Valuable & 0.31 & 0.37 & 0.28 & 0.32 \\
Cognitive & 0.15 & 0.21 & 0.09 & 0.24 \\
Constructive & 0.29 & 0.32 & 0.28 & 0.32 \\
General coefficient (CCF) & 0.25 & 0.3 & 0.216 & 0.293 \\
\hline
\end{tabular}

Based on the fact that the experimentally obtained criterion for the reliability of differences in the coefficients is much larger than the tabulated one, this allows asserting with confidence that there is a statistically significant difference between the results of the stating and control sections.

A comparison of the formation coefficients of professional competence of students of technical specialities of the control groups indicates the absence of a statistically significant 
difference between them according to the results of the stating and control sections: the coefficients vary within a low level (Table 2). The calculated difference between the means is 0.27 , the reliability criterion is 1.13 , which is much less than the table. A slight increase in the coefficients is due, in the authors' opinion, to a slight increase in students' knowledge in the process of double passage of the same diagnostic procedures. The general dynamics of the formation coefficients of professional competence of students of technical specialities of experimental and control groups are presented in Table 3.

Table 3

The Dynamics of the Coefficients of the Formation of Professional Competence of

Students of Technical Specialities According to the Results of the Control Stage of the Experiment

\begin{tabular}{lcccccc}
\hline & \multicolumn{5}{c}{ Experimental groups } \\
\cline { 2 - 7 } $\begin{array}{l}\text { Professional competency } \\
\text { component (coefficient) }\end{array}$ & \multicolumn{2}{c}{ EG1 } & \multicolumn{2}{c}{ EG2 } & \multicolumn{2}{c}{ EG3 } \\
\cline { 2 - 7 } & $\begin{array}{c}\text { Ascertai- } \\
\text { ning }\end{array}$ & Control & $\begin{array}{c}\text { Ascertai- } \\
\text { ning }\end{array}$ & Control & $\begin{array}{c}\text { Ascertai- } \\
\text { ning }\end{array}$ & Control \\
\hline Valuable & 0.28 & 0.72 & 0.3 & 0.65 & 0.27 & 0.69 \\
Cognitive & 0.18 & 0.81 & 0.12 & 0.74 & 0.09 & 0.86 \\
Constructive & 0.33 & 0.69 & 0.26 & 0.61 & 0.29 & 0.68 \\
General coefficient (CCF) & 0.263 & 0.74 & 0.226 & 0.66 & 0.216 & 0.74 \\
\hline
\end{tabular}

A generalisation of all the data obtained, the presence of a statistically significant difference between the formation factors of professional competence of students of technical specialities of experimental groups before and after applying the optimal pedagogical trajectory makes it possible to assert the correctness of the hypothesis of the study.

\section{Conclusions}

In view of the absence of a unified approach to the diagnosis of professional competence of students of technical specialities in the study of geometric-graphical disciplines, in particular, the uncertainty of diagnostic procedures, based on their own understanding of the essence of professional competence of a technical specialist as an integrative personality-professional phenomenon, which consists of a value (social professional relations), cognitive (system of professional knowledge) and constructive (system of professional skills) components and ensures the success of their social and professional adaptation, future professional activities and life activity in general due to the harmonisation of their own needs, individual goals and social norms, a set of diagnostic methods of professional the competence of future technical specialists, which are included to measure: 1) value component - Test of the formation of knowledge and skills; Questionnaire of motivation 
for professional success; 2) cognitive component - author's didactic test; 3) structural component - Methodology "sorting: diagnosis of the main trends in behaviour in a real group"; Questionnaire of tolerance-intolerance to uncertainty; author's scale of selfesteem of professional skills.

According to the requirements for modern pedagogical research, experimental verification of certain scientific and methodological foundations for the formation of professional competence of students of technical specialities, including organisational and pedagogical conditions, was conducted:

1) the ascertaining stage at which the primary level of formation of professional competence was studied under the conditions of the existing composition of factors;

2) the formative stage, which was aimed at introducing certain experimental factors (organisational and pedagogical conditions related to the optimisation of the pedagogical trajectory);

3) the control stage providing for secondary diagnostics of the level of formation of professional competence of students of technical specialities after the introduction of experimental factors.

A generalisation of all the data obtained, the presence of a statistically significant difference between the formation factors of professional competence of students of technical specialities of experimental groups before and after the optimisation of the pedagogical trajectory makes it possible to assert the effectiveness of theoretically defined, justified and implemented organisational and pedagogical conditions.

\section{References}

Alhajri, S. A. (2010). The importance of creativity in teaching graphic design in Arab world. Design Principles and Practices, 4(1), 59-69.

Anamova, R. R., \& Nartova, L. G. (2019). Geometric spatial ability as an element of cognitive learning process. Periodico Tche Quimica, 16(32), 542-550.

Cicalò, E., Causin, A., \& Solci, M. (2019). Mathegraphics: Integrating graphic, geometrical and algebraic representation in teaching and research through a dialogical Approach. Advances in Intelligent Systems and Computing, 809, 1511-1522. https://doi.org/10.1007/978-3-31995588-9_134

Clark, A., Ernst, J., \& Scales, A. (2008, June 22-25). The attitudes and opinions of students toward technical graphics: Preliminary survey results. [Conference presentation]. Annual Conference \& Exposition. Pittsburgh, Pennsylvania.

Dulić, O., Krklješ, M., \& Aladžić, V. (2019). Teaching design to civil and architectural engineering students - A diagram-based approach. International Journal of Engineering Education, 35(4), 1141-1156. 
Gachago, D., Morris, A., \& Simon, E. (2011). Engagement levels in a graphic design clicker class: Students' perceptions around attention, participation and peer learning. Journal of Information Technology Education: Research, 10(1), 253-269. https://doi.org/10.28945/1507

Guedes, K. B., De Sá Guimarães, M., \& Méxas, J. G. (2012). Virtual reality using stereoscopic vision for teaching/learning of descriptive geometry. Proceedings of International Conference on Mobile, Hybrid, and On-line Learning (pp. 24-30). Valencia, Spain.

Kuchkarova, D. F., \& Achilova, D. A. (2019). Quality management of engineering graphics teaching. Advances in Intelligent Systems and Computing, 809, 1624-1630. https://doi. org/10.1007/978-3-319-95588-9_145

Lasserre, B. (2012). Speaking the critique in graphic design: The role of metaphor. Art, Design and Communication in Higher Education, 10(1), 51-66. https://doi.org/10.1386/adch.10.1.51_1

Lemke, H. U., \& Engelhom, M. (1986). Work Stations for Computer-Graphic Display in Medical Imaging. Biomedizinische Technik, 31(6), 143-149. https://doi.org/10.1515/bmte.1986.31.6.143

Leonavičienè, T., \& Suboč, O. (2014). Peculiarity of perception of mathematical disciplines by future engineers. Pedagogika, 113(1), 159-169.

Littlejohn, D. (2017). Disciplining the graphic design discipline: The role of external engagement, mediating meaning, and transparency as catalysts for change. Art, Design and Communication in Higher Education, 16(1), 33-51. https://doi.org/10.1386/adch.16.1.33_1

Moszkowicz, J. (2013). American pragmatism and graphic design: Retrieving the historical and philosophical constitutions of a "non-theoretical” approach. Design Journal, 16(3), 315-338. https://doi.org/10.2752/175630613X13512595147032

Nelin, Y. (2004). Discipline "functional and nanoelectronics". Modern Problems of Radio Engineering, Telecommunications and Computer Science. Proceedings of the International Conference TCSET (p. 625). Lviv, Ukraine.

Núñez, P. J., García-Plaza, E., Martín, A. R., \& Egido, A. (2011). An integrated methodology for the teaching of computer aided tools for automated machining. Materials Science Forum, 692, 8-15. https://doi.org/10.4028/www.scientific.net/MSF.692.8

Shangina, E. I. (2019). Development of Polytechnic Education in the Conditions of Integration of General-Engineering and Special Disciplines. IOP Conference Series: Earth and Environmental Science, 272(3). Retrieved from: https://iopscience.iop.org/artic le/10.1088/1755-1315/272/3/032158/pdf

Taras, I. (2019). Features of teaching the graphic discipline courses for different specialty students. Advances in Intelligent Systems and Computing, 809, 2257-2261. https://doi.org/10.1007/9783-319-95588-9_215

Tikhonov-Bugrov, D. E., Abrosimov, S. N., \& Diumin, V. A. (2018). Basic principles of engineering and computer graphics teaching to future professionals. Proceedings of GraphiCon 2018 - 28th International Conference on Computer Graphics and Vision (pp. 389-392). Tomsk, Russian Federation. 
Trofimov, V. T., \& Korolev, V. A. (2019). Logical and Graphic Models of the Structure and Contents of the General Theory of Engineering Geology and its Disciplines. Moscow University Geology Bulletin, 74(5), 496-503. https://doi.org/10.3103/S0145875219050132

Zhuykova, O., Bozek, P., Sosnovich, E., \& Akhmedzianov, E. (2019). Applying additive technologies to teaching graphic disciplines in a technical university. Proceedings of ICETA 2019 - 17th IEEE International Conference on Emerging eLearning Technologies and Applications (pp. 829-835). The High Tatras, Slovakia, https://doi.org/10.1109/ICETA48886.2019.9040094

\title{
Integruotas požiūris ị geometrinių-grafinių dalykų dèstymą universitete
}

\author{
Rushana R. Anamova ${ }^{1}$, Tatyana M. Khvesyuk ${ }^{2}$
}

1 Maskvos aviacijos institutas (Nacionalinis tyrimų universitetas), Inžinerinės grafikos katedra, Volokolamsko plentas 4, RU-125993 Maskva, Rusijos Federacija, anamova5078@kpi.com.de

2 Maskvos aviacijos institutas (Nacionalinis tyrimų universitetas), Inžinerinès grafikos katedra, Volokolamsko plentas 4, RU-125993 Maskva, Rusijos Federacija. khvesyuk5078@kpi.com.

\section{Santrauka}

Straipsnyje keliama tyrimo hipotezè - visapusiškas požiūris ị geometrinių-grafinių dalykų dėstymą padidins studentų profesinès kompetencijos lygị. Daroma prielaida, kad mokymosi procesas organizuojamas atsižvelgiant ị efektyviausią pedagoginę trajektoriją.

Tyrimo tikslui pasiekti buvo atlikta keletas pedagoginių eksperimentų, kurių metu ịvertintas techninių specialybių studentų profesinių kompetencijų formavimosi lygis bei jų pasiekti tobulinimosi rezultatai baigus dalyko studijas.

Autoriai išnagrinejjo kiekvieno diagnostinio sluoksnio rezultatus kiekvienam techninių specialybių studentų profesinès kompetencijos komponentui eksperimentinèje ir kontrolinèje grupèse, o po to juos nagrinèjo pagal bendrą profesinès kompetencijos formavimosi koeficientą.

Kontrolinio matavimo rezultatai atskleidžia, kad igyvendinus formuojamąsias priemones žymiai padidèja studentų žinių ir igūdžių reflektavimo lygis. Apibendrinus visus gautus tyrimo duomenis, nustatyti statistiškai reikšmingi skirtumai tarp techninių specialybių studentų profesinès kompetencijos formavimo veiksnių eksperimentinėse grupèse prieš optimalios pedagoginès trajektorijos pritaikymą ir po jo. Tai patvirtina iškeltos hipotezės teisingumą.

Esminiai žodžiai: aukštasis mokslas, geometriniai-grafiniai dalykai, pedagoginè trajektorija, profesine kompetencija. 